\title{
Unusual reactivity of thiosemicarbazides towards 2,3-diphenylcyclopropenone: synthesis of new pyridazinethiones and 1,2,4-triazolo[4,3-b]pyridazinethiones
}

\author{
Ashraf A. Aly,* Alaa A. Hassan, Mohsen A.-M. Gomaa, and Essmat M. El-Sheref \\ Chemistry Department, Faculty of Science, El-Minia University, El-Minia, A. R. Egypt \\ E-mail: ashraf160@yahoo.com
}

\begin{abstract}
New pyridazinethiones and 1,2,4-triazolo[4,3-b]pyridazinethiones have been obtained during the reaction of thiosemicarbazide and its 1,4-disubstituted derivatives with 2,3-diphenylcyclopropenone. The reaction of this cyclopropenone with two equivalents of thiosemicarbazide afforded the corresponding 1,2,4-triazolo[4,3-b]pyridazinethiones. However, the reaction of $N$ substituted hydrazino derivatives of thiosemicarbazides with the cyclopropenone occurs with stoichiometric amounts of the starting materials to produce pyridazinethiones. The reaction mechanism, in both cases, was described as a formal [3+3]-cycloaddition.
\end{abstract}

Keywords: Thiosemicarbazides, 2,3-diphenylcyclopropenone, pyridazinethiones, 1,2,4-triazolo[4,3-b]-pyridazinethiones, [3+3]-cycloaddition

\section{Introduction}

Thiosemicarbazides are easily cyclized by the action of acids, bases or oxidants, therefore they are useful versatile building blocks for the preparation of heterocyclic ring systems. Some time ago, we investigated the reactions of thiosemicarbazides with $\pi$-deficient compounds. As a result we synthesized many heterocyclic ring systems such as thiazoles, thiazines, thiadiazoles, thiadiazines, pyrazines and indazoles. ${ }^{1,2}$

Cyclopropenones undergo several interesting cycloaddition reactions and they may be useful starting materials for a variety of compounds. ${ }^{3,4}$ They are also reactive towards dipolar reagents and compounds having a reactive $\pi$-system. ${ }^{5}$ The reaction pattern is sometimes complex, but recent extensive investigations have established the utility of these molecules as building blocks for the construction of larger molecules. It is expected that the use of cyclopropenones as $\mathrm{C}_{3}$ synthetic blocks will find a broader applicability in the field of synthetic chemistry in the future. 2,3-Diphenylcyclopropenone (1) can be represented by the resonance structures 1a-c (equivalent 
to 1d), ${ }^{5-7}$ which contain a three-membered ring of $\mathrm{sp}^{2}$ carbons coupled to the electron-donor substituents on the phenyls seem to stabilize these structures.

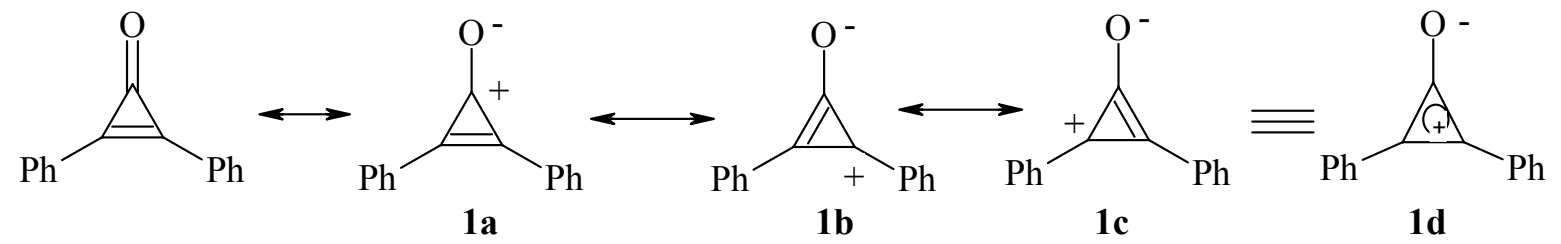

Figure 1. Resonance structures of 2,3-diphenylcyclopropenone

The systematic interest in the use of the cyclopropenone chemistry is to construct a wide variety of heterocycles. ${ }^{8}$ Diphenylcyclopropenone (1) has been found to react with a wide range of imines and other compounds containing the $\mathrm{C}=\mathrm{N}$ moiety, usually to form azacyclopentenones (pyrrolinones) via formal [2+3] cycloaddition reactions. ${ }^{9-14}$ By contrast, the reaction of 1 with guanidine and its alkyl and/or aryl derivatives gave the corresponding 5,6-dihydro-4(1H)pyrimidinone via a formal [3+3] cycloaddition reaction. ${ }^{15}$ In general, cyclopropenone is amphiphilic, reacting readily with both nucleophilic and electrophilic reagents. Moreover, cyclopropenones are strained ring ambident electrophiles with a tendency to form ring opened products, their reaction with nucleophiles has the possibility of carbonyl or conjugate addition. ${ }^{9-17}$ Recently, we have found that the reactions of aroylphenylthioureas with $\mathbf{1}$ in acetic acid afforded the diasteromers of 3-(3-aroyl-1-substituted-thioureido)-2,3-diphenylcinnamic acids. $^{18}$

Generally, the $N^{2}$ of thiosemicarbazides is described as a softer nucleophilic center than the harder and powerful terminal nitrogen $N^{1}$. 2,3-Diphenylcyclopropenone (1) is susceptible to nucleophilic attack by $N^{1}$ and undergoes cyclization to form six-membered rings; the reaction can be described as a [3+3]-cycloaddition. Therefore, we decided in this publication to study the chemistry of $\mathbf{1}$, especially towards bidentate nucleophiles such as thiosemicarbazides.

\section{Results and Discussion}

Herein, we report a general overall view of the reaction between thiosemicarbazides $\mathbf{2 a - e}$ and $\mathbf{1}$ (Scheme 1). In the case of reacting equal equivalents of $\mathbf{2 a - c}$ and $\mathbf{1}$, thin layer chromatographic analysis proved that compound $\mathbf{1}$ was still recovered, whereas 3a-c and $\mathbf{4 a - c}$ were obtained in low yields. However, the reaction between 1 and two equivalents of 2 a-c proceeded without recovery of 1 and produced compounds 3a-c and 4a-c. In different manner, the reaction of $2 \mathbf{d}, \mathbf{e}$ with 1 was carried out by reacting equal equivalents of the two starting materials to afford compounds 5d,e (Scheme 1). We chose thiosemicarbazides 2a-e having various different substituents on the $\mathrm{NH}$ in the $\mathrm{NH}-\mathrm{NH}_{2}$ group in order to examine their reactivity, which might 
affect the course of the reaction (Scheme 1). Elemental analyses and IR, NMR $\left({ }^{1} \mathrm{H},{ }^{13} \mathrm{C}, \mathrm{COSY}\right.$ $\mathrm{C}-\mathrm{H}$ and $\mathrm{H}-\mathrm{H}$ ) and mass spectra were in good agreement with the assigned structures of compounds 3a-c and 4a-c. For example, the IR spectroscopy of the triazolopyridazines 3a gave characteristic triazolo- $\mathrm{C}=\mathrm{N}$ band at $\mathrm{v}=1610$, pyridazine $\mathrm{C}=\mathrm{C}$ at $\mathrm{v}=1560$, and $\mathrm{NH}$ and $\mathrm{NH}_{2}$ absorptions at $v=3300-3180$, and a strong $\mathrm{OH}$ absorption appeared at $v=3450 \mathrm{~cm}^{-1}$. The IR spectra of compounds 3b,c showed the presence of pyridazine-NH as a sharp strong band between $v=3280-3200$, whereas the $\mathrm{OH}$ absorption was noted between $v=3480-3450 \mathrm{~cm}^{-1}$. Bands characteristic of vibration coupling of $\mathrm{C}=\mathrm{S}$ and $\mathrm{C}-\mathrm{N}$ groups appeared between $v=1140$ $1090 \mathrm{~cm}^{-1}$. The ${ }^{1} \mathrm{H}$ NMR spectra of $\mathbf{3 b}, \mathbf{c}$ revealed two broad singlets at $\delta=5.50-5.60$ and 9.009.10 corresponding to $\mathrm{OH}$ and triazole-NH protons, respectively. Additionally, the phenyl- (or benzyl-)NH and pyridazine-NH protons appeared superimposed on the aromatic protons. The elemental analysis and mass spectrum of 3a proved its molecular formula as $\mathrm{C}_{17} \mathrm{H}_{15} \mathrm{~N}_{5} \mathrm{OS}$. The ${ }^{1} \mathrm{H}$ NMR spectra confirmed the structure of compound 3a by the appearance of four broad singlets at $\delta=4.50,5.40,7.40$ and 9.00 corresponding to $\mathrm{NH}_{2}, \mathrm{OH}$, pyridazine- (along with the aromatic protons) and triazole-NH protons, respectively. The COSY $\mathrm{C}-\mathrm{H}$ spectra proved the presence of $\alpha$-quaternary $\mathrm{C}-\mathrm{OH}$. The ${ }^{13} \mathrm{C}$ NMR spectra of 3a-c supported the ${ }^{1} \mathrm{H}$ NMR spectral data by the appearance of the chiral $\mathrm{C}-\mathrm{OH}$ at $\delta=115.0-115.6$, whereas the $\mathrm{C}=\mathrm{S}$ resonated at $\delta=$ 180.6-182.4. Direct one-bond attached hydrogen-carbon correlations were established by ${ }^{1} \mathrm{H}$, ${ }^{13} \mathrm{C}$ - COSY (HETCOR). Accordingly, COSY C-H of compounds 3a and 4a indicated the relation between the phenyl carbons and their protons. Besides, a relation was found between the carbon signals of C-7 and C-8 and protons of the phenyl groups attached to these carbon atoms. The NMR spectral data of compounds 4a-c supported the proposed structures. The mass spectrum and elemental analysis of $\mathbf{4 a}$ established its molecular formula as $\mathrm{C}_{17} \mathrm{H}_{13} \mathrm{~N}_{5} \mathrm{~S}$. The ${ }^{1} \mathrm{H}$ NMR spectrum of $4 \mathbf{a}$ showed two multiplets for eleven protons. The free $\mathrm{NH}_{2}$ protons resonated at $\delta=$ 5.20, whereas the NH-pyridazine was superimposed on the aromatic protons. The ${ }^{13} \mathrm{C} \mathrm{NMR}$ spectrum showed the C-3, $-6,-7,-8,-9$ at $\delta=150.0,194.0,122.4,122.6,160.4$, respectively. The ${ }^{13} \mathrm{C}-135 / 90$-DEPT spectra of $\mathbf{4 c}$ supported the presence of the quaternary benzylic- $\mathrm{CH}_{2}$ at $\delta=$ 48.5 (the $\mathrm{CH}_{2}$ proton appeared in the ${ }^{1} \mathrm{H}$ NMR spectrum as a broad singlet at $\delta=4.60$ ). No significant $\mathrm{SH}$ resonance appeared in the NMR spectra which suggests that the thione form predominates. The $\mathrm{C}=\mathrm{S}$ carbon appeared for $\mathbf{4 a - c}$ between $\delta=194.0$ and 196.0. The formation of 3a-e and 4a-e can be rationalized by nucleophilic attack of 2 at its terminal hydrazino nitrogen upon the carbonyl group in $\mathbf{1}$ to form $\mathbf{6}$. The single bond in the strained three-membered ring in $\mathbf{6}$ is then opened and adds thereafter to the thione group of another molecule of $\mathbf{2}$ (Figure 2). Then, the nucleophilic $\mathrm{NH}_{2}$ attacks the activated $\mathrm{C}=\left({ }^{+} \mathrm{OH}\right)$ to form intermediate 7 . A second fused ring is then formed via an intramolecular nucleophilic attack of the NH-pyridazine on the thione group. That was accompanied with elimination of one molecule of substituted amine and hydrogen sulfide from $\mathbf{7}$, to give the stable fused heterocyclic compound 3 (Figure 2). Dehydration of $\mathbf{3}$, under the reaction conditions, occurs to give 4 (Figure 2). Isolation of compounds 3a-c both confirmed the structure of 4a-c, and proved elimination of a water molecule to occur as the ultimate step (Figure 2). In our case, the illustrated pathways leading to 
3a-c and 4a-c seem very likely, since compounds having a hydrazino function condensed with $\mathbf{1}$ to give the corresponding hydrazo derivatives of cyclopropenone (Scheme 1). ${ }^{19}$ Moreover, the suggested mechanism was strongly supported by the reported literature ${ }^{20}$ especially in the case of the formation of $\mathbf{6}$ in its tautomer form. Consequently, this tautomer can act as a reactive nucleophile.

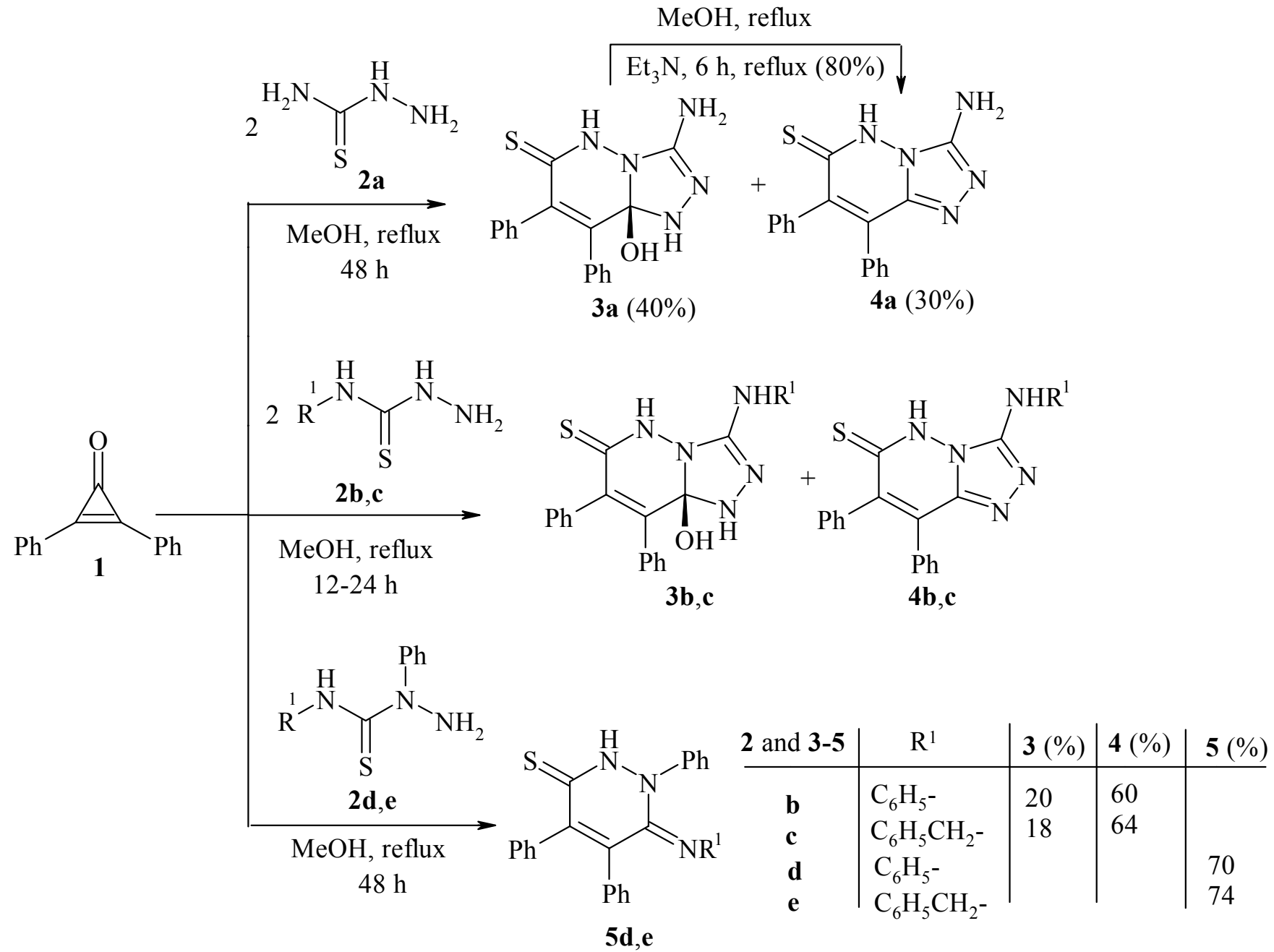

Scheme 1. Reactions of thiosemicarbazides 2a-e with 1.

The structure of the obtained products (Scheme 1) excluded pathway such as that proposed by Eicher, ${ }^{9,10}$ which depends on the nucleophilic attack of the terminal nitrogen of 2 to the olefinic carbon in $\mathbf{1}$ (pathway b). It is also possible that elimination of amine and hydrogen sulfide molecules might occur to give the intermediate 7 and thus produce product 8 (Figure 2). That was also excluded, due to the disappearance of the range of chemical shifts expected for the hydrazino NH-NH protons in the ${ }^{1} \mathrm{H}$ NMR spectra. Previous literature on the chemistry of thiosemicarbazides towards $\pi$-acceptors supported the formation of a pyridazino-NH rather than 
the formation of the hydrazino $\mathrm{NH}-\mathrm{NH}^{2}$ The conversion of $\mathbf{3 a}$ into $\mathbf{4 a}$ was carried out experimentally by refluxing compound 3a in methanol containing a few drops of triethylamine. Product 4a was then obtained in $80 \%$ yield. A long period of refluxing $\mathbf{3 a}$ in the absence of triethylamine gave $\mathbf{4 a}$ in only $30 \%$ yield.

Surprisingly, on reacting the substituted hydrazine group $\mathbf{2 d , e}$ with $\mathbf{1}$, the reaction produced the corresponding pyridazinethiones $\mathbf{5 d , e}$ (Scheme 1). The structure of compounds $\mathbf{5 d , e}$ is well established using the traditional spectroscopic tools such as IR, NMR $\left({ }^{1} \mathrm{H},{ }^{13} \mathrm{C}\right)$ and mass spectra, in addition to elemental analyses. In NOE experiments of compound 5e, irradiating the benzylic$\mathrm{CH}_{2}$ protons $(\delta=5.20)$ caused a strong positive enhancement to the attached phenyl protons, and also slightly affected the two protons of the other phenyl group.

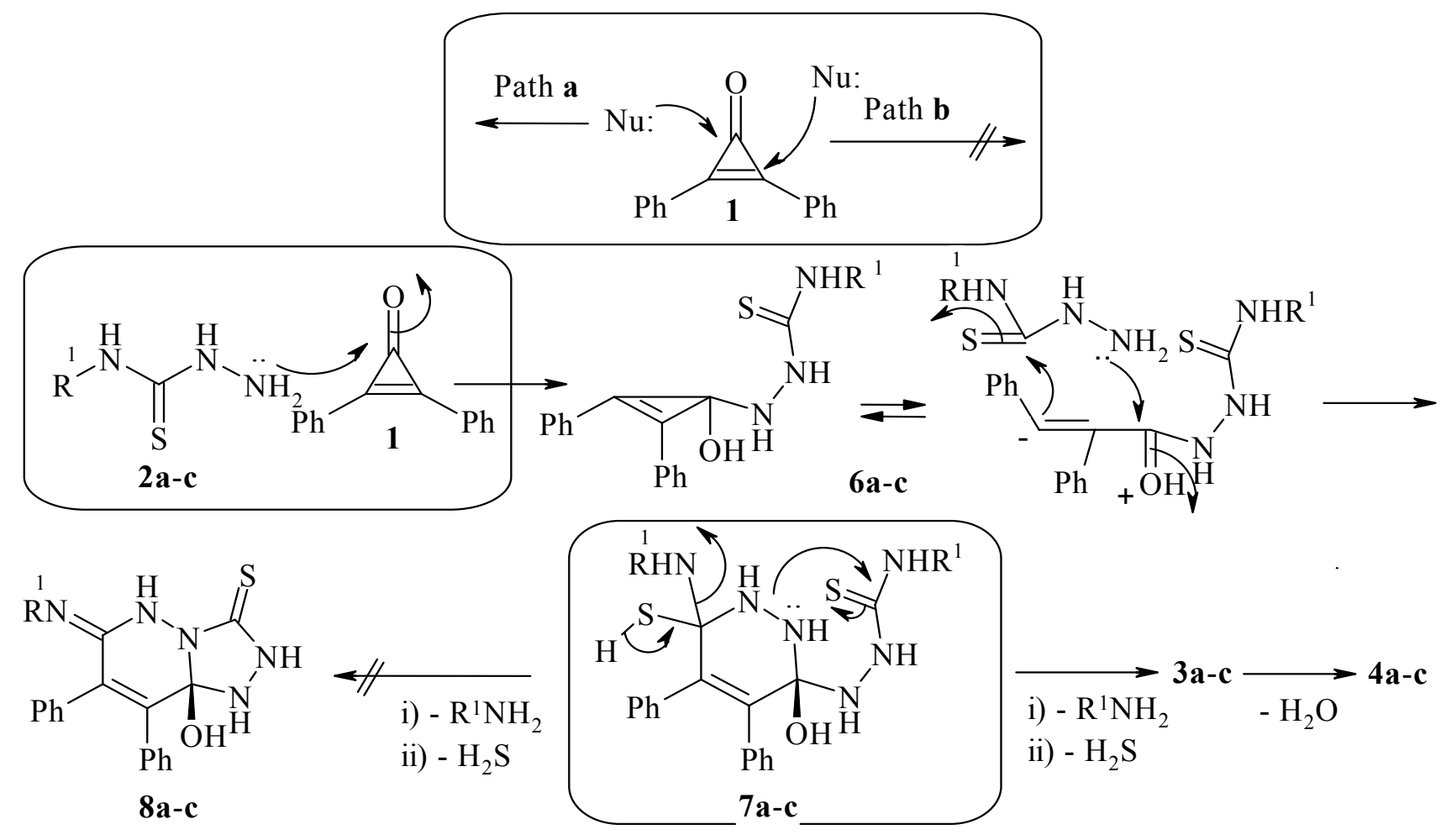

Figure 2. Mechanistic pathway of 1,2,4-triazolo-[4,3- $b]$ pyridazine-6-thiones 3a-c and 4a-c.

The ${ }^{13} \mathrm{C}$ NMR spectrum of $\mathbf{5 e}$ showed six distinctive carbon signals at $\delta=50.4,122.0,124.6$, 138.9, 150.8 and 190.6 corresponding to benzylic- $\mathrm{CH}_{2}, C-4,-5, \mathrm{Ph}-\mathrm{C}-\mathrm{N}, C-6$ and -3 , respectively. ${ }^{1} \mathrm{H},{ }^{13} \mathrm{C}$ - COSY (HETCOR) of compound 5e indicated the relations between the phenyl carbons and their protons. Correlation was also found between the carbon signals of C-4 and C-5 and the protons of the phenyl groups connected to these carbon atoms, along with strong correlation between $\mathrm{C}-6(\delta=150.8)$ and the benzyl- $\mathrm{CH}_{2}$ protons. The proposed mechanism for the formation of $\mathbf{5 d}, \mathbf{e}$ is based upon normal condensation of the free hydrazine $\mathrm{NH}_{2}$ with the carbonyl of 1 (Figure 3) to give 9. Thereafter, we propose that another nucleophilic addition 
occurs to the thione group, leaving it as thiolate anion, which spontaneously adds to the azo group in one step to give 10 (Figure 3). Under the reaction conditions, another type of intramolecular rearrangement occurs involving ring opening (to form the stable thione group) accompanied with a proton transfer to give the stable pyridazinethiones $\mathbf{5 d , e}$ (Figure 3). The processes showing the formation of intermediates $\mathbf{9}$ and $\mathbf{1 0}$ and including the nucleophilic addition to the thione group from the strained cyclopropenehydrazone followed by bi-cyclic formation, have been shown by other workers during the addition of cyclopropenone to 4-vinyl substituted 1-azetines. ${ }^{20 a}$

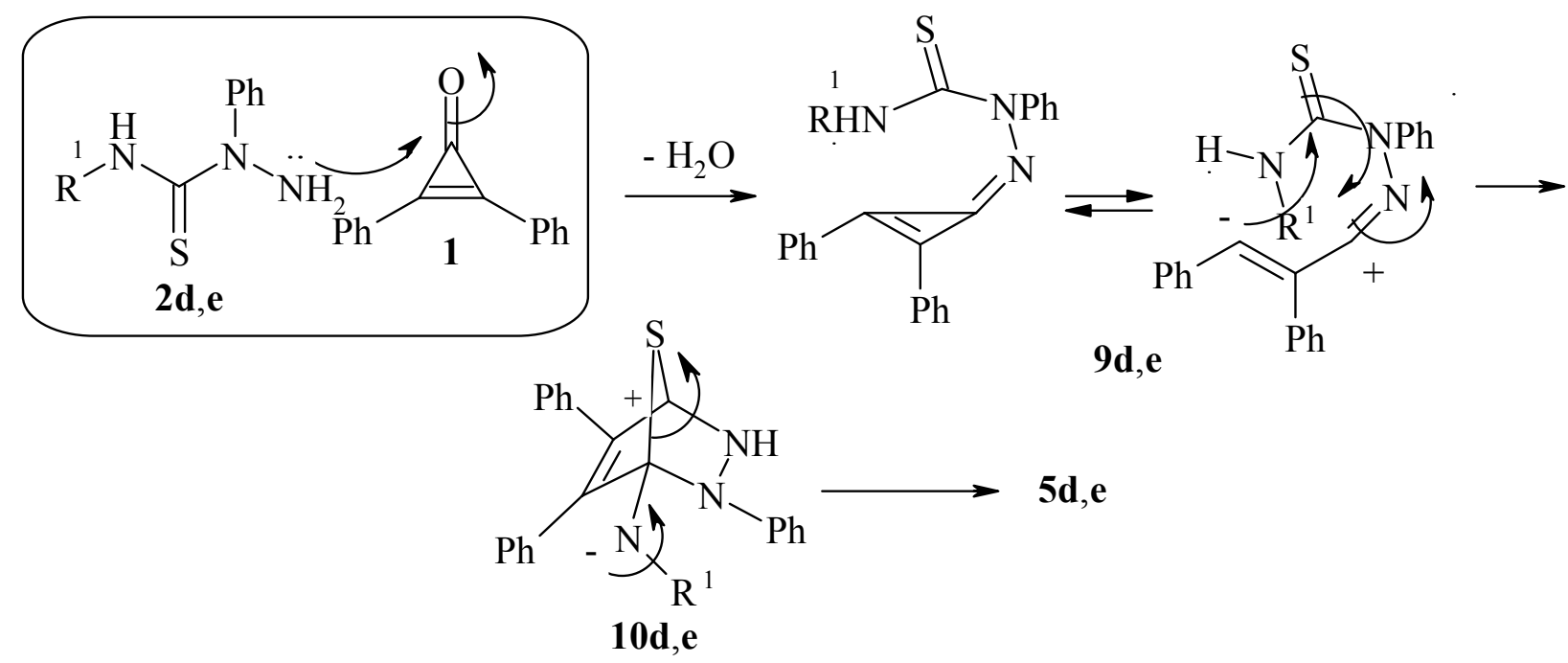

Figure 3. Mechanistic pathway of pyridazinethiones 5d,e.

The abnormal behavior of $\mathbf{2 d , e}$ towards $\mathbf{1}$ might be attributed to the steric factors arising from the presence of the bulky phenyl group on the nitrogen derived from $N^{2}$ of $\mathbf{2 d}$,e, which prevents further mutual addition between the intermediate 6 (Figure 2) and another molecule of $\mathbf{1}$. The comparative higher yield of $\mathbf{5 e}$ related to $\mathbf{5 d}$ can be explained as due to the higher basic character of the benzylic hydrazine $2 \mathbf{e}$ compared with that in $\mathbf{2 d}$ (Scheme 1). Moreover, the stereoview ${ }^{21}$ of compounds $\mathbf{5 d}$ and $\mathbf{5 e}$, as optimized by molecular mechanics, showed that formation $\mathbf{5 e}$ has a lower steric energy value $(8.57 \mathrm{Kcal} / \mathrm{mol})$ than $\mathbf{5 d}(10.49 \mathrm{Kcal} / \mathrm{mol})$.

In conclusion we have developed a method for the synthesis of pyridazinethione and 1,2,4triazolopyridazinethione systems. The reaction and products presented here provide insight into spontaneous reactions between thiosemicarbazides 2a-e and 2,3-diphenylcyclopropenone (1). In a fairly complex and multi-step process, triazolopyridazinethiones 3a-c, 4a-c and pyridazinethiones $\mathbf{5 d}$,e were formed. The prospective biological and pharmaceutical activities of the obtained products are of great interest. ${ }^{22-24}$ 


\section{Experimental Section}

General Procedures. All mps were recorded on a Gallenkamp apparatus. The IR spectra were obtained on Shimadzu 470 spectrophotometer using potassium bromide pellets. The ${ }^{1} \mathrm{H}$ NMR $\left(400.134 \mathrm{MHz}\right.$ ) and ${ }^{13} \mathrm{C}$ NMR $(100.6 \mathrm{MHz})$ spectra were measured in $\mathrm{CDCl}_{3}$ using Bruker a $\mathrm{AM}$ 400 with TMS as an internal standard. Coupling constants are expressed in Hz. Mass spectra were recorded on a Finnigan MAT 8430 instrument at $70 \mathrm{eV}$. Elemental analyses were carried out in the Microanalysis Center of the Institut für Anorganische Chemie, Technische Universität Braunschweig. For preparative thin layer chromatography (PLC), glass plates $(20 \times 48 \mathrm{~cm})$ were covered with a slurry of silica gel Merck $\mathrm{PF}_{254}$ and air-dried using the solvents listed for development. Zones were detected by quenching of indicator fluorescence upon exposure to 254 $\mathrm{nm}$ light; elution of the different bands with toluene afforded the pure products. The abbreviations: triaz $=$ triazole and pyrid $=$ pyridazine.

\section{Starting materials}

4-Phenylthiosemicarbazide (2b) $)^{25,26}$ 4-benzylthiosemicarbazide (2c) ${ }^{26,27}$ and 1,4-disubstituted thiosemicarbazides $(\mathbf{2 d}, \mathbf{e})^{28}$ were prepared according to literature procedures. Thiosemicarbazide (2a) and 2,3-diphenylcyclopropenone (1) were bought from Fluka.

\section{General experimental procedure}

Reactions of 2a-c with 1. A $250 \mathrm{~cm}^{3}$ two-necked round bottom flask was charged with dry methanol $(100 \mathrm{~mL})$ containing $2 \mathrm{mmols}$ of $\mathbf{2 a - c}$ and $(0.412 \mathrm{mg}, 1 \mathrm{mmol})$ of $\mathbf{1}$. The mixture was gently refluxed under stirring for $12-48 \mathrm{~h}$ (the reaction was monitored by TLC). The solvent was evaporated in vacuo and the residue was separated by PLC (silica gel) with toluene: ethyl acetate (2:1). Compounds 4a-c migrated faster than compounds 3a-c. Products were obtained after recrystallization from the stated solvents.

3-Amino-8 $\alpha(S)$-hydroxy-1,8 $\alpha$-dihydro-7,8-diphenyl-1,2,4-triazolo[4,3-b]pyridazine-6-thione (3a). Yellow crystals, mp (ethanol) $122{ }^{\circ} \mathrm{C}$, yield $0.27 \mathrm{~g}(40 \%)$; IR (KBr): $v 3450$ (s, OH), 3300 3180 (s, NH and $\mathrm{NH}_{2}$ ), 3030-2990 (Ar-CH), 1610 (s, C=N), 1560 (s, C=C), 1115 (m), 998 (s) $\mathrm{cm}^{-1} ; \lambda_{\max }\left(\mathrm{CH}_{3} \mathrm{CN}, \lg \varepsilon, \mathrm{nm}\right): 398(3.94) ;{ }^{1} \mathrm{H} \mathrm{NMR}\left(400 \mathrm{MHz}, \mathrm{CDCl}_{3}\right): \delta 4.50\left(2 \mathrm{H}, \mathrm{br} \mathrm{s}, \mathrm{NH}_{2}\right)$, $5.40(1 \mathrm{H}, \mathrm{br} \mathrm{s}, \mathrm{OH}, \mathrm{H}-8 \mathrm{a}), 6.50-6.80(3 \mathrm{H}, \mathrm{m}, \mathrm{Ph}-\mathrm{H}), 7.20-7.60(6 \mathrm{H}, \mathrm{m}, \mathrm{Ph}-\mathrm{H}$ and pyrid-NH), $7.86(2 \mathrm{H}, \mathrm{dd}, J=8.0,2.0, \mathrm{Ph}-\mathrm{H}), 9.00\left(1 \mathrm{H}, \mathrm{s}\right.$, triaz-NH); ${ }^{13} \mathrm{C} \mathrm{NMR}\left(100.6 \mathrm{MHz}, \mathrm{CDCl}_{3}\right): \delta 115.0$ (C-8a), 126.0, 126.4 (para-Ph-H), 128.2, 129.6, 130.4, $130.6(\mathrm{Ph}-\mathrm{CH}), 131.4,132.8$ (C-7 and 8), 133.0, 133.5 (Ph-C), $148.2(\mathrm{C}=\mathrm{N}), 180.6$ (C-6); EI-MS m/z: \% 337 [M+1 ] (100), 321 (24), 304 (30), 288 (28), 278 (30), 262 (20), 260 (60), 184 (48), 77 (54), 60 (18). Anal. Calcd. For $\mathrm{C}_{17} \mathrm{H}_{15} \mathrm{~N}_{5} \mathrm{OS}$ (337.41): C, 60.52; H, 4.48; N, 20.76; S, 9.50. Found: C, 60.40; H, 4.50; N, 20.80; $\mathrm{S}, 9.48$.

8 $\alpha(S)$-Hydroxy-1,8 $\alpha$-dihydro-7,8-diphenyl-3-phenylamino-1,2,4-triazolo[4,3-b]pyridazine6-thione (3b). Yellow crystals, mp (ethanol) $290{ }^{\circ} \mathrm{C}$, yield $0.17 \mathrm{~g}(20 \%)$; IR (KBr): $v 3460(\mathrm{~m}$, OH), 3280-3200 (s, NH), 3050-2995 (m, Ar-CH), 1620 (s, C=N), 1585 (s, C=C), 1090 (s), 996 
(m) $\mathrm{cm}^{-1} ; \lambda_{\max }\left(\mathrm{CH}_{3} \mathrm{CN}, \lg \varepsilon, \mathrm{nm}\right): 412$ (4.06); ${ }^{1} \mathrm{H} \mathrm{NMR}\left(400 \mathrm{MHz}, \mathrm{CDCl}_{3}\right): \delta 5.50(1 \mathrm{H}$, br s, $\mathrm{OH}, \mathrm{H}-8 \mathrm{a}), 6.56-6.80$ (5H, m, Ph-H), 7.60-7.94 (9H, m, Ph-H, pyrid-and $\mathrm{Ph}-\mathrm{NH}), 8.00$ (2H, dd, $J=8.4,2.0, \mathrm{Ph}-\mathrm{H}), 8.10(1 \mathrm{H}, \mathrm{dd}, J=8.4,2.0, \mathrm{Ph}-\mathrm{H}), 9.00\left(1 \mathrm{H}, \mathrm{s}\right.$, triaz-NH); ${ }^{13} \mathrm{C} \mathrm{NMR}(100.6$ $\mathrm{MHz}, \mathrm{CDCl}_{3}$ ): $\delta 115.6$ (C-8a), 126.0, 126.6, 127.0 (para-Ph-H), 128.0, 128.2, 128.4, 129.2, 130.0, $130.4(\mathrm{Ph}-\mathrm{CH}), 131.4,132.0(\mathrm{C}-7$ and -8$), 132.8,133.4,133.8(\mathrm{Ph}-\mathrm{C}), 148.8(\mathrm{C}=\mathrm{N})$, 182.4 (C-6); EI-MS m/z: \% $413\left[\mathrm{M}^{+}\right]$(100), 396 (18), 380 (16), 336 (48), 321 (24), 304 (30), 278 (34), 259 (26), 260 (60), 184 (34), 77 (40), 60 (28). Anal. Calcd. For $\mathrm{C}_{23} \mathrm{H}_{19} \mathrm{~N}_{5} \mathrm{OS}$ (413.50): C, 66.81; H, 4.63; N, 16.94; S, 7.75. Found: C, 66.70; H, 4.60; N, 16.90; S, 7.74.

3-Benzylamino-8 $\alpha(S)$-hydroxy-1,8 $\alpha$-dihydro-7,8-diphenyl-1,2,4-triazolo[4,3-b]pyridazine-6thione (3c). Pale yellow crystals, mp (ethanol) $240{ }^{\circ} \mathrm{C}$, yield $0.15 \mathrm{~g}(18 \%)$; IR (KBr): v 34803450 (m, OH), 3280-3210 (s, NH), 3080-2980 (w, Ar-CH), 2980-2860 (w, alip-CH), 1630 (s, $\mathrm{C}=\mathrm{N}), 1590(\mathrm{~m}, \mathrm{C}=\mathrm{C}), 1115(\mathrm{~s}), 994(\mathrm{~m}) \mathrm{cm}^{-1}$; $\lambda_{\max }\left(\mathrm{CH}_{3} \mathrm{CN}, \mathrm{lg} \varepsilon, \mathrm{nm}\right): 400$ (4.08); ${ }^{1} \mathrm{H} \mathrm{NMR}$ $\left(400 \mathrm{MHz}, \mathrm{CDCl}_{3}\right): \delta 5.60(1 \mathrm{H}, \mathrm{s}, \mathrm{OH}, \mathrm{H}-8 \mathrm{a}), 4.80\left(2 \mathrm{H}\right.$, br s, $\left.\mathrm{CH}_{2} \mathrm{Ph}\right), 6.60-6.76(5 \mathrm{H}, \mathrm{m}, \mathrm{Ph}-\mathrm{H})$, 7.40-8.00 (9H, m, Ph-H, pyrid- and benzyl-NH), 8.18 (2H, dd, $J=8.2,2.2, \mathrm{Ph}-\mathrm{H}), 8.04$ (1H, dd, $J=8.2,2.0, \mathrm{Ph}-\mathrm{H}), 9.10\left(1 \mathrm{H}, \mathrm{s}\right.$, triaz-H); ${ }^{13} \mathrm{C} \mathrm{NMR}\left(100.6 \mathrm{MHz}, \mathrm{CDCl}_{3}\right): \delta 54.00\left(\mathrm{CH}_{2}-\mathrm{Ph}\right)$, 115.4 (C-8a), 126.4, 126.8, 127.0 (para-Ph-H), 128.0, 128.6, 128.8, 129.6, 130.2, $130.4(\mathrm{Ph}-$ $\mathrm{CH}), 132.0,132.4$ (C-7 and -8), 132.6, 133.8, $133.4(\mathrm{Ph}-\mathrm{C}), 150.0(\mathrm{C}=\mathrm{N}), 181.0$ (C-6); EI-MS m/z: \% 428 [M+1] (30), $427\left[\mathrm{M}^{+}\right]$(100), 410 (18), 350 (22), 336 (24), 294 (18), 274 (26), 256 (16), 223 (30), 193 (18), 77 (50), 60 (22). Anal. Calcd. for $\mathrm{C}_{24} \mathrm{H}_{21} \mathrm{~N}_{5} \mathrm{OS}$ (427.53): C, 67.43; H, 4.95; N, 16.38; S, 7.50. Found: C, 67.40; H, 4.90; N, 16.30; S, 7.38.

3-Amino-7,8-diphenyl-1,2,4-triazolo[4,3-b]pyridazine-6-thione (4a). Orange crystals, $\mathrm{mp}$ (methanol) $160{ }^{\circ} \mathrm{C}$, yield $0.19 \mathrm{~g}(30 \%)$; IR (KBr): v 3290-3250 (s, NH), 3068-2992 (w, Ar-CH), $1610(\mathrm{~s}, \mathrm{C}=\mathrm{N}), 1580(\mathrm{~m}, \mathrm{C}=\mathrm{C}) 1110(\mathrm{~s}), 996(\mathrm{~m}) \mathrm{cm}^{-1} ; \lambda_{\max }\left(\mathrm{CH}_{3} \mathrm{CN}, \lg \varepsilon, \mathrm{nm}\right): 410(3.98) ;{ }^{1} \mathrm{H}$ NMR (400 MHz, $\left.\mathrm{CDCl}_{3}\right): \delta 5.20(2 \mathrm{H}$, br s, NH$), 6.60-6.70(2 \mathrm{H}, \mathrm{m}, \mathrm{Ph}-\mathrm{H}), 7.40-7.68(9 \mathrm{H}, \mathrm{m}$, $\mathrm{Ph}-\mathrm{H}$ and pyrid-NH); ${ }^{13} \mathrm{C}$ NMR $\left(100.6 \mathrm{MHz}, \mathrm{CDCl}_{3}\right): \delta 122.4,122.6(\mathrm{C}-7$ and -8$), 126.8,127.2$ (para-Ph-H), 128.0, 129.2, 130.6, 130.8 (2Ph-CH), 133.4, 133.8 (Ph-C), 150.0 (C-3), 160.4 (C8a), 194.0 (C-6); EI-MS m/z: \% 320 [M+1] (20), 319 [M+] (100), 304 (24), 288 (24), 278 (24), 262 (18), 260 (62), 184 (46), 77 (50), 60 (18). Anal. Calcd. for $\mathrm{C}_{17} \mathrm{H}_{13} \mathrm{~N}_{5} \mathrm{~S}$ (319.39): C, 63.93; H, 4.10; N, 21.93; S, 10.04. Found: C, 64.00; H, 4.10; N, 21.90; S, 9.98.

7,8-Diphenyl-3-phenylamino-1,2,4-triazolo[4,3-b]pyridazine-6-thione (4b). Orange crystals, mp (acetonitrile) $190{ }^{\circ} \mathrm{C}$, yield $0.47 \mathrm{~g}(60 \%)$; IR (KBr): v 3320-3260 (s, NH), 3060-2985 (w, $\operatorname{Ar}-\mathrm{CH}), 1610(\mathrm{~s}, \mathrm{C}=\mathrm{N}), 1560(\mathrm{~m}, \mathrm{C}=\mathrm{C}), 1112(\mathrm{~s}), 998(\mathrm{~s}) \mathrm{cm}^{-1} ; \lambda_{\max }\left(\mathrm{CH}_{3} \mathrm{CN}, \mathrm{lg} \varepsilon, \mathrm{nm}\right): 430$ (4.2); ${ }^{1} \mathrm{H}$ NMR (400 MHz, $\left.\mathrm{CDCl}_{3}\right): \delta 6.60-6.80(5 \mathrm{H}, \mathrm{m}, \mathrm{Ph}-\mathrm{H}), 7.30-7.82(10 \mathrm{H}, \mathrm{m}, \mathrm{Ph}-\mathrm{H}$ and pyrid-NH), $8.30(1 \mathrm{H}, \mathrm{s}, \mathrm{Ph}-\mathrm{NH}) ;{ }^{13} \mathrm{C} \mathrm{NMR}\left(100.6 \mathrm{MHz}, \mathrm{CDCl}_{3}\right): \delta 123.0,123.2(\mathrm{C}-7$ and -8$)$, 126.4, 127.6, 128.0 (para-Ph-H), 128.4, 128.6, 129.8, 130.2, 130.6, 130.8 (2Ph-CH), 133.6, 134.2 (Ph-C), 138.9 (NH-C-Ph), 152.0 (C-3), 158.9 (C-8a), 194.8 (C-6); EI-MS m/z: \% 395 $\left[\mathrm{M}^{+}\right]$(100), 362 (18), 318 (42), 302 (38), 288 (28), 278 (30), 262 (30), 226 (24), 184 (18), 77 (34), 60 (22). Anal. Calcd. for $\mathrm{C}_{23} \mathrm{H}_{17} \mathrm{~N}_{5} \mathrm{~S}$ (395.39): C, 69.85; H, 4.33; N, 17.71; S, 8.11. Found: C, 69.00; H, 4.30; N, 17.66; S, 8.08. 
3-Benzylamino-7,8-diphenyl-1,2,4-triazolo[4,3-b]pyridazine-6-thione (4c). Orange crystals, $\mathrm{mp}$ (acetonitrile) $142{ }^{\circ} \mathrm{C}$, yield $0.52 \mathrm{~g}(64 \%)$; IR (KBr): v 3240-3220 (s, NH), 3065-2990 (m, $\mathrm{Ar}-\mathrm{CH}), 2980-2960$ (m, aliph-CH), $1600(\mathrm{~s}, \mathrm{C}=\mathrm{N}), 1570(\mathrm{~m}, \mathrm{C}=\mathrm{C}), 1110(\mathrm{~m}), 996(\mathrm{~m}) \mathrm{cm}^{-1}$; $\lambda_{\max }\left(\mathrm{CH}_{3} \mathrm{CN}, \lg \varepsilon, \mathrm{nm}\right): 412(4.0) ;{ }^{1} \mathrm{H} \mathrm{NMR}\left(400 \mathrm{MHz}, \mathrm{CDCl}_{3}\right): \delta 4.60\left(2 \mathrm{H}, \mathrm{br}, \mathrm{s}, \mathrm{CH}_{2} \mathrm{Ph}\right), 6.70-$ $6.90(5 \mathrm{H}, \mathrm{m}, \mathrm{Ph}-\mathrm{H}), 7.38-7.90\left(11 \mathrm{H}, \mathrm{m}, \mathrm{Ph}-\mathrm{H}\right.$ and pyrid-NH), $8.30\left(1 \mathrm{H}\right.$, br s, benzyl-NH); ${ }^{13} \mathrm{C}$ NMR (100.6 MHz, $\left.\mathrm{CDCl}_{3}\right): \delta 48.5\left(\mathrm{CH}_{2} \mathrm{Ph}\right), 123.2,123.6(\mathrm{C}-7$ and -8), 126.8, 127.4, 128.0 (para-Ph-H), 128.6, 128.8, 129.6, 130.0, 130.4 (Ph-CH), 132.4, 134.0 (Ph-C), 152.6 (C-3), 156.8 (C-8a), 196.0 (C-6); EI-MS m/z: \% 410 [M+1] (22), 409 [M $\mathrm{M}^{+}$(100), 362 (18), 318 (42), 302 (38), 288 (28), 278 (30), 262 (30), 226 (24), 184 (18), 77 (34), 60 (22). Anal. Calcd. for $\mathrm{C}_{24} \mathrm{H}_{19} \mathrm{~N}_{5} \mathrm{~S}$ (409.52): C, 70.39; H, 4.68; N, 17.10; S, 7.83. Found: C, 70.20; H, 4.60; N, 17.00; S, 7.78.

Reactions of 2d,e with 1 . By the same procedure, dry methanol $(50 \mathrm{~mL})$ containing $1 \mathrm{mmol}$ of 2d,e and $1 \mathrm{mmol}(0.412 \mathrm{mg})$ of 1 was gently refluxed under stirring for $48 \mathrm{~h}$ (the reaction was monitored by TLC). The solvent was evaporated in vacuo and the residue was separated by PLC (silica gel) with toluene: ethyl acetate (3:1). Compounds 5d,e were recrystallized from the stated solvents.

1,4,5-Triphenyl-6[(Z)-phenylimino-1,6-dihydro-2 $H$-pyridazine-3-thione $\quad(5 d)$ Yellow crystals, mp (ethanol) $290{ }^{\circ} \mathrm{C}$, yield $0.30 \mathrm{~g}$ (70\%); IR (KBr): $v$ 3280-3220 (s, NH), 3060-2990 $(\mathrm{m}, \mathrm{Ar}-\mathrm{CH}), 1580(\mathrm{~s}, \mathrm{C}=\mathrm{N}), 1560(\mathrm{~m}, \mathrm{C}=\mathrm{C}), 1115(\mathrm{~s}), 996(\mathrm{~s}) \mathrm{cm}^{-1} ; \lambda_{\max }\left(\mathrm{CH}_{3} \mathrm{CN}, 1 \mathrm{~g} \varepsilon, \mathrm{nm}\right): 420$ (4.0); ${ }^{1} \mathrm{H}$ NMR (400 MHz, $\left.\mathrm{CDCl}_{3}\right): \delta 6.62-6.64$ (2H, m, ortho-Ph-H-C-4), 6.80-7.16 (5H, m, Ph$\mathrm{H})$, 7.20-7.24 (2H, m, ortho-Ph-H- $\left.N^{1}\right)$, 7.34-7.48 (5H, m, Ph-H), 7.54-7.56 (2H, m, ortho-Ph-H$N-\mathrm{C}-6), 7.70-7.86(4 \mathrm{H}, \mathrm{m}, \mathrm{Ph}-\mathrm{H}), 8.30\left(1 \mathrm{H}\right.$, br s, pyrid-H); ${ }^{13} \mathrm{C} \mathrm{NMR}\left(100.6 \mathrm{MHz}, \mathrm{CDCl}_{3}\right): \delta$ 124.6, 124.8 (C-4 and -5), 126.0, 126.4, 127.3 (para-Ph-H), 128.0, 128.2, 128.4, 128.6, 128.8, 130.0 (2Ph-CH), 131.0, 131.6, 132.6 (Ph-C), 133.0, 133.2 (2Ph-H), 133.6 (para-Ph-H), 138.6 (N-C-Ph), 150.6 (C-6), 190.4 (C-3); EI-MS m/z: \% $431\left[\mathrm{M}^{+}\right]$(40), 430 [M-1] (100), 339 (16), 312 (60), 278 (38), 207 (24), 184 (20), 165 (24), 129 (40), 77 (50), 55 (60). Anal. Calcd. $\mathrm{C}_{28} \mathrm{H}_{21} \mathrm{~N}_{3} \mathrm{~S}$ (431.56): C, 77.93; H, 4.90; N, 9.74; S, 7.43. Found: C, 77.80; H, 4.90; N, 9.70; S, 7.48 .

6- $[(E)$-Benzylimino-1,4,5-triphenyl-1,6-dihydro-2 $H$-pyridazine-3-thione (5e). Yellow crystals, mp (ethanol) $220{ }^{\circ} \mathrm{C}$, yield $0.33 \mathrm{~g}$ (74\%); IR (KBr): v 3200-3180 (m, NH), 3080-2960 (m, Ar-CH), 2960-2850 (w, aliph-CH), $1618(\mathrm{~m}, \mathrm{C}=\mathrm{N}), 1570(\mathrm{~s}, \mathrm{C}=\mathrm{C}), 1112$ (s), 996 (m) cm ${ }^{-1}$; $\lambda_{\max }\left(\mathrm{CH}_{3} \mathrm{CN}, \lg \varepsilon, \mathrm{nm}\right): 418$ (3.90); ${ }^{1} \mathrm{H} \mathrm{NMR}\left(400 \mathrm{MHz}, \mathrm{CDCl}_{3}\right): \delta 5.20\left(2 \mathrm{H}, \mathrm{br}, \mathrm{s}, \mathrm{CH}_{2} \mathrm{Ph}\right.$ ), 6.82-6.84 (2H, m, ortho-Ph-H-C-4), 6.90-7.20 (5H, m, Ph-H), 7.30-7.34 (2H, m, ortho-Ph-H- $\left.N^{1}\right)$, 7.50-7.90 (9H, m, Ph-H), $8.00(2 \mathrm{H}, \mathrm{dd}, J=8.4,1.8, \mathrm{Ph}-\mathrm{H}), 8.34\left(1 \mathrm{H}, \mathrm{s}\right.$, pyrid-H); ${ }^{13} \mathrm{C}$ NMR $\left(100.6 \mathrm{MHz}, \mathrm{CDCl}_{3}\right): \delta 50.4\left(\mathrm{CH}_{2} \mathrm{Ph}\right), 122.0,124.6(\mathrm{C}-4$ and -5$), 125.6,126.0,126.8$ (para-PhH), 127.8, 128.0, 128.2, 128.6, 128.8, 130.4 (2Ph-CH), 131.2, 131.8, 132.4 (Ph-C), 133.2, 133.6 (2Ph-H), 133.8 (para-Ph-H), 138.9 (N-C-Ph), 150.8 (C-6), 190.6 (C-3); EI-MS m/z: \% (EI)] 445 $\left[\mathrm{M}^{+}\right]$(60), 368 (20), 309 (24), 207 (18), 167 (30), 105 (12), 91 (100), 55 (40). Anal. Calcd. for $\mathrm{C}_{29} \mathrm{H}_{23} \mathrm{~N}_{3} \mathrm{~S}$ (445.59): C, 78.17; H, 5.20; N, 9.43; S, 7.20. Found: C, 78.10; H, 5.22; N, 9.40; S, 7.28 . 


\section{Acknowledgment}

Prof Dr Ashraf A Aly thanks the DAAD foundation for financial support to stay in Germany, Braunschweig, Institute for Organic Chemistry.

\section{References}

1. Hassan, A. A.; Mourad, A. E.; El-Shaieb, K. M.; Abou-Zeid, A. H. J. Heterocycl. Chem. 2006, 43, 471 .

2. Hassan, A. A.; Mohamed, N. K.; Shawky, A. M.; Döpp, D. Arkivoc 2003, 118.

3. (a) Takahashi, M.; Kadowaki, Y.; Uno, Y.; Nakamoto, Y. Heterocycles 1999, 51, 2035, and references therein. (b) Potts, K. T.; Braum, J. S. Chem. Rev. 1974, 74, 1974. (c) Eicher, T.; Weber, J. Top. Curr. Chem. 1975, 52, 1.

4. (a) Kogen, H.; Kiho, T.; Tago, K.; Miyamoto, S.; Fujioka, T.; Otsuka, N.; Suzuki-Konagai, K.; Ogita, T. J. Am. Chem. Soc. 2000, 122, 1842. (b) Okuda, T.; Yokose, K.; Furumai, T.; Maruyama, H. B. J. Antibiot. 1984, 37, 718. (c) Bohlmann, F.; Jakupovic, J.; Mueller, L.; Schuster, A. Angew. Chem., Int. Ed. 1981, 20, 292.

5. (a) Vol'pin, M. E.; Koreshkov, Yu. D.; Kursanov, D. N. Izv. Akd. Nauk SSSR, Otd. Khim. Nauk 1959, 560. (b) Breslow, R.; Haynie, R.; Mirra, J. J. Am. Chem. Soc. 1959, 81, 247.

6. Breslow, R.; Posner, J.; Krebs, A. J. Am. Chem. Soc. 1963, 85, 234.

7. Breslow, R.; Eicher, T.; Krebs, A.; Peterson, R. A.; Posner, J. J. Am. Chem. Soc. 1965, 87, 1320.

8. For representative papers see: (a) Kascheres, A.; Schumacher, H. C.; Rodrigues, R. A. F. J. Heterocycl. Chem. 1997, 34, 757. (b) Kascheres, A.; Rodrigues, R. A. F. Tetrahedron 1996, 52, 12919; (c) Kascheres, A.; Correa Filho, J.; Cunha. S. Tetrahedron 1993, 49, 381. (d) Kascheres. A.; Kascheres, C.; Braga, A. C. H. J. Org. Chem. 1993, 58, 1702. (e) Cunha, S.; Kascheres, A. J. Heterocycl. Chem. 1993, 30, 567. (f) Kascheres, A.; Kascheres, C.; Rodrigues, J. A. R. Synth. Commun. 1984, 14, 905. (g) Kascheres, A.; Reyes, J. L.; Fonseca, S. M. Heterocycles 1984, 22, 2529. (h) Kascheres, C.; Kascheres, A.; Pilli, P. S. H. J. Org. Chem. 1980, 45, 5340.

9. Eicher, T.; Weber, J. L. Tetrahedron Lett. 1974, 1381.

10. Eicher, T.; Abdesaken, F.; Franke, G.; Weber, J. L. Tetrahedron Lett. 1975, 3915.

11. Eicher, T.; Weber, J. L.; Chatila, G. Liebigs Ann. Chem. 1978, 1203.

12. Eicher, T.; Krause, D. Tetrahedron Lett. 1979, 1213.

13. Eicher, T.; Franke, G. Liebigs Ann. Chem. 1981, 1337.

14. Eicher, T.; Krause, D. Synthesis 1986, 899.

15. Okawara, T.; Kato, R.; Yamasaki, T.; Yasuda, N.; Furukawa, M. Heterocycles 1986, $24,4$.

16. Bilinski, V.; Steinfels, M. A.; Dreiding, A. S. Helv. Chim. Acta 1972, 55, 1065. 
17. Jensen, K. A.; Baccaro, H. R.; Buchardt, O.; Olsen, G. G.; Pedersen, C.; Toft, J. Acta Chem. Scand. 1961, 15, 1109.

18. Aly, A. A.; Ahmed, E. K.; El-Mokadam, K. M. J. Sulf. Chem. 2007 (in press).

19. Turan-Zitouni, G.; Sivaci, M.; Kilic, F. S.; Erol, K. J. Med. Chem.2001, 36, 685.

20. (a) Hemming, K.; O'Gorman, P. A.; Page, M. I. Tetrahedron Lett. 2006, 47, 425. (b) Cunha, S.; Kascheres, A. J. Braz. Chem. Soc. 2001, 12, 481. (c) Kascheres, C. M. J. Braz. Chem. Soc. 2003, 14, 945.

21. Allinger, N. L. MM2 (91) force field Program, obtained from Quantum Chemistry Program, Indiana University; Molecular Mechanics PM3 Program (ACD/3D), Advanced Chemical Development Inc., Toronto, Canada (1988).

22. Sondhi, S. M.; Sharma, V. K.; Singhal, N.; Verma, R. P.; Shukla, R.; Raghubir, R.; Dubey, M. P. Phosphorus, Sulfur, Silicon Relat. Elem. 2000, 156, 21.

23. Burdulene, D.; Palaima, A.; Stumbryavichyute, Z.; Talaikite, Z. Pharm. Chem. J. 1999, 33, 191.

24. For reviews on $[1,2,4]$ triazolopyridazines, see: (a) Schneller, S. W. In Comprehensive Heterocyclic Chemistry, Vol. 5, Part 4A; Katritzky, A. R.; Rees, C. W. Eds.; Pergamon Press: Oxford, 1984; p 847. (b) Hajós, G. In Comprehensive Heterocyclic Chemistry II, Vol. 8, Katritzky, A. R.; Rees, C. W.; Scriven, E. F. V. Eds.; Pergamon Press: Oxford, 1996; p 417.

25. Stanovnik, B.; Tisler, M. J. Org. Chem. 1960, 25, 2234.

26. Eberhardt, U.; Rabe, J.; Anger, I.; Schmidt, J.; Grunert, H. East German Patent 1971, 83, 559; Chem. Abstr. 1973, 78, 96674g.

27. Paranjpe, M. G.; Deshpande, P. H. Indian J. Chem. 1969, 7, 186.

28. Noto, R.; Lo Meo, P.; Gruttadauria, M.; Werber, G. J. Heterocyl. Chem. 1999, $36,667$. 